\title{
Klip-kompresyon ve ağırlık düşürme modelleriyle oluşturulmuş deneysel omurilik yaralanması modellerinde oksidan-antioksidan parametrelerin analizi
}

\section{Analysis of oxidant-antioxidant parameters in experimental spinal cord injury models created with clip-compression and weight-drop models}

\author{
Ercan Bal, Şahin Hanalioğlu, Aydın Sinan Apaydın, Ceylan Bal, Almila Şenat,Berrak Gümüşkaya \\ Öcal, Burak Bahadır, Ömer Faruk Türkoğlu
}

\section{Özet}

Amaç: Deneysel omurilik yaralanmalarında hasarın takibi ve hücrelerin hasara yanıtını değerlendirmek ana unsurlardan biridir. Bu çalışmada iki farklı deneysel omurilik travma modelinde serum ve dokuda oksidanantioksidan maddelerin değişimi incelenerek, bu modellerin spinal travma için kullanılabilirliği araştırılmıştır.

Gereç ve yöntem: Çalışmada 3 grupta 6'şar adet Wistar rat kullanıldı. Kontrol grubuna (A grubu) sadece laminektomi yapıldı. Ağırlık grubuna (B grubu) laminektomi ve ağırlık düşürme modeli ile, klip-kompresyon grubuna (C grubu) laminektomi ve klip kompresyon tekniği ile spinal kord hasarı oluşturuldu. Fonksiyonel olarak 12. saat, 1., 3., 5. ve 7. gün Basso-Beattie and Bresnahan (BBB) skorları ile değerlendirildi. Biokimyasal olarak 12. saatte, 1., 5. ve 7. gün alınan kuyruk kanlarında oksidan-antioksidan maddeler incelendi. 7. gün sakrifiye edilen deneklerin omurilik dokularında Total antioksidan kapasite (TAS), Total oksidan kapasite (TOS) ve OSI (oksidatif stres indeksi) bakıldı.

Bulgular: A grubuna göre B ve C grubunda Disülfid (SS)/Total tiol (TT), SS/Native tiol (NT) ve NT/TT oranları 7. günde anlamlı olarak farklı bulunmuştur $(p=0,018)$. Katalaz değerleri arasında 7. günde $C$ grubunda $A$ ve $B$ grubuna göre anlamlı farklılık saptanmış ve $C$ grubunda en belirgin katalaz düşüşü kaydedilmiştir $(p=0,012)$. IMA (iskemi modifiye albümin) erken evrede artsa da hasarın 3. gününden itibaren tekrar azalıp 7. gün normale yakın değerlere gelmiştir. C ile B grubu kıyaslandığında parametrelerin C grubunda daha anlamlı değişiklik gösterdiği görülmüştür.

Sonuç: Travma modellerinde oksidatif-antioksidatif markerlar hasarın şiddetini göstermede ve takibinde kullanılabilir. Klip kompresyon yöntemi, serumda oksidatif stres parametrelerini ölçmek ve omurilik travmasını değerlendirmek için daha başarılı bir deneysel omurilik yaralanması yöntemidir.

Anahtar kelimeler: Oksidatif stres, spinal kord yaralanması, TAS, TOS.

Bal E, Hanalioğlu Ş, Apaydın AS, Bal C, Şenat A, Gümüşkaya Öcal B, Bahadır B, Türkoğlu ÖF. Klip-kompresyon ve ağırlık düşürme modelleriyle oluşturulmuş deneysel omurilik yaralanması modellerinde oksidan-antioksidan parametrelerin analizi. Pam Tıp Derg 2020;13:775-783.

\begin{abstract}
Purpose: The follow-up of damage and evaluation of the cell's response to damage in experimental spinal cord injuries are among the main factors. In this study, the changes of serum and tissue oxidant-antioxidant substances in two different experimental spinal cord trauma models were investigated and usability of these spinal cord trauma models were examined.
\end{abstract}

Ercan Bal, Dr. Öğr. Üye. Ankara Yıldırım Beyazıt Üniversitesi Tıp Fakültesi, Beyin ve Sinir Cerrahisi Anabilim Dalı, Ankara, Türkiye, e-posta: drercanbal@gmail.com (orcid.org/0000-0003-0138-2090) (Sorumlu Yazar)

Şahin Hanalioğlu, Op. Dr. Ankara Hacettepe Üniversitesi Tıp Fakültesi, Beyin ve Sinir Cerrahisi Anabilim Dalı, Ankara, Türkiye, e-posta: sahinhanalioglu@gmail.com (orcid.org/0000-0003-4988-4938)

Aydın Sinan Apaydın, Dr. Ankara Şehir Hastanesi, Beyin ve Sinir Cerrahisi Kliniği, Ankara, Türkiye, e-posta: dr.sinanapaydin@yahoo.com (orcid. org/0000-0002-2916-9550)

Ceylan Bal, Dr. Ankara Yıldırım Beyazıt Üniversitesi Tıp Fakültesi, Biokimya Anabilim Dalı, Ankara, Türkiye, e-posta: ceylandemirbal@gmail. com (orcid.org/0000-0002-1678-1281)

Almila Şenat, Dr. Ankara Yıldırım Beyazıt Üniversitesi Tıp Fakültesi, Biokimya Anabilim Dalı, Ankara, Türkiye, e-posta: almilasenat@gmail.com (orcid.org/0000-0002-5806-562X)

Berrak Gümüşkaya Öcal, Doç. Dr. Ankara Yıldırım Beyazıt Üniversitesi Tıp Fakültesi, Patoloji Anabilim Dalı, Ankara, Türkiye, e-posta: drberrakgumuskaya@gmail.com (orcid.org/0000-0003-0599-8968)

Burak Bahadır, Dr. Ankara Şehir Hastanesi, Beyin ve Sinir Cerrahisi Kliniği, Ankara, Türkiye, e-posta: bubahadir@hotmail.com (orcid.org/00000003-2456-8170)

Ömer Faruk Türkoğlu, Doç. Dr. Ankara Şehir Hastanesi, Beyin ve Sinir Cerrahisi Kliniği, Ankara, Türkiye, e-posta: ofturkoglu@yahoo.com (orcid. org/0000-0001-9375-1169) 
Material and methods: In this study, 6 Wistar rats were used in each 3 groups. Laminectomy was performed in the group A. Spinal cord injury was created with laminectomy and weight drop model in group B, and laminectomy and clip compression technique in the group $\mathrm{C}$. The animals were examined functionally at the 12th hour and on the 1st day, 3rd day, 5th day and 7th day. Biochemically, oxidant-antioxidant substances were examined in the tail blood taken at the 12th hour, on the 1st, 5th and 7th days. Total antioxidant capacity (TAS), Total oxidant capacity (TOS) and OSI (oxidative stress index) were examined in the spinal tissues of the rats sacrificed on the 7th day.

Results: Disulphide (SS) / Total thiol (TT), SS / Native thiol (NT) and NT / TT ratios were significantly different in group $\mathrm{B}$ and $\mathrm{C}$ compared to group $\mathrm{A}$ on 7 th day $((p=0.018)$. On the 7 th day, a significant difference was found between the catalase values in group $C$ compared to groups $A$ and $B$, and the most significant catalase decrease was noted in group C $(p=0.012)$. Although IMA (ischemia-modified albumin) increased at an early stage, it decreased again from the 3rd day of the injury and reached nearly normal values on the 7 th day. When the $\mathrm{C}$ and $\mathrm{B}$ groups were compared, it was seen that the parameters showed more significant changes in the C group.

Conclusion: In trauma models, oxidative-antioxidative markers can be used to demonstrate the severity of the damage and to follow-up the progression of the damage. Clip compression method is a more successful method for measuring oxidative-antioxidative parameters in serum and evaluating spinal cord trauma.

Key words: Oxidative stress, spinal cord injury, TAS, TOS.

Bal E, Hanalioglu S, Apaydin AS, Bal C, Senat A, Gumuskaya Ocal B, Bahadir B, Turkoglu OF. Analysis of oxidant-antioxidant parameters in experimental spinal cord injury models created with clip-compression and weight-drop models. Pam Med J 2020;13:775-783.

\section{Giriş}

Günümüzde halen önemli bir morbidite ve mortalite nedeni olan ve insidansı 10,5/100000 kişi olarak tahmin edilen spinal kord yaralanmasında uygun bir deneysel omurilik yaralanması modeli oluşturma çabaları 20. yy'ın başına kadar uzanmaktadır [1]. İlk olarak Allen 1911'de ağırlık düşürme modeli ile deneysel spinal kord yaralanma modelini tariflemiş, ve sonrasında birçok omurilik yaralanma modeli geliştirilmiştir [2]. Bu modellerle, insan omurilik yaralanmasının mümkün olduğunca yeniden oluşturulması hedeflenmiştir [3]. En çok kullanılan modellemeler ağırlık düşürme ve klip kompresyon teknikleri olmuştur [2-5]. Deneysel omurilik yaralanması modellerinde histopatolojik değişiklikler kadar, biokimyasal değişiklikler de tedavi yaklaşımları için önemlidir [4, 6-9]. Oksidan-antioksidan dengesizliğinin spinal kord iyileşmesindeki rolü anlaşıldıktan sonra, antioksidan kapasite terapotik yanıtın etkinliğini de gösterir olmuştur [8, 10-13]. Oksidanantioksidan kapasite oluşumu ve zamana göre değişimini bilmek, terapotik çalışmalar açısından anahtar noktalardan biridir.

Bu çalışmada deneysel omurilik yaralanma modellerinde en sık kullanılan iki yöntem olan ağırlık düşürme ve klip-kompresyon metodları arasında biokimyasal olarak oksidatif ve antioksidatif yanıtlar değerlendirilmiş ve sonuçlar fonksiyonel olarak karşılaştırılarak bu iki modelden hangisinin biokimyasal olarak daha uygun bir deneysel modelleme olduğu araştırılmıştır.

\section{Gereç ve yöntem}

Bu çalışmanın deney protokolü Kobay A.Ş. Yerel Etik Kurulu tarafından onaylanmıştır. Yetişkin dişi Wistar-Hannover albino ratlar (her biri $250 \mathrm{~g}$ ile $300 \mathrm{~g}$ arasında olan; $\mathrm{n=18} 3$ eşit gruba ayrıldı. Deney sırasında tüm gruplar, 12 saatlik aydınlık ve karanlık döngüleri ile, standart bir postoperatif bakım odasında $\left(20^{\circ} \mathrm{C}\right.$ ila $25^{\circ} \mathrm{C}$ 'de $\% 50-60$ nemde polikarbonat kafeslerde) ve standart beslenme koşulları ile tutuldu. Deney sürecinde deneklerde kayıp ve enfeksiyon izlenmedi.

Dokuda total antioksidan statüs (TAS) ve total oksidatif status ölçümü için ticari kit kullanıldı $[14,15]$. Doku protein miktarı Lowry metodu ile belirlendi [16]. Oksidatif stres indeksi (OSi), TOS değerlerinin TAS değerlerine bölünmesiyle elde edildi (OSI (Arbitrary Unit) = (TOS, $\mu \mathrm{mol}$ $\mathrm{H}_{2} \mathrm{O}_{2}$ eq/L) / (TAS, $\mu$ mol Trolox eq/L).

Serum tiyol disülfid ölçümü Erel ve Neşelioğlu tarafından oluşturulan metodla otomatikanalizör (Roche, cobas 501, Mannheim, Germany) kullanılarak ölçüldü. Bu metodda; örnekteki disülfit bağları $\mathrm{NaBH}_{4}$ tarafından fonksiyonel tiyol gruplarına dönüştürüldü. Örnekteki total 
tiyol içeriği Ellman ayıracıyla hesaplandı. Serum disülfit miktarı ise (serum total tiyol-serum native tiyol) / 2 formülüyle belirlendi [17].

Serum iskemi modifiye albümin (IMA) düzeyleri Bar-Or yöntemine göre belirlendi [18]. Sonuçlar absorbans birimleri (ABSU) olarak ifade edildi. Aktivitesi Goth'ın yöntem ile ölçüldü [19].

\section{Deney grupları}

A grubu (Kontrol grubu, $n=6$ ): Sadece laminektomi yapıldı

$B$ grubu (Ağırlık düşürme grubu, $n=6$ ): Laminektomi+ağırlık düşürme

C grubu (Klip-kompresyon grubu, $\mathrm{n}=6$ ): Laminektomi+klip-kompresyon

\section{Deney}

Denekler rastgele 3 eşit gruba (A: Kontrol grubu $(n=6), B$ : Ağırlık düşürme grubu $(n=6), C$ : Klip kompresyon grubu $(n=6)$ ) ayrıldı. Altı saatlik açlıktan sonra $1 \mathrm{mg} / \mathrm{kg}$ ketamin (Ketalar, Pfizer, New York, USA) ve $1 \mathrm{mg} / \mathrm{kg}$ xylazine (Alfazyne, Alfasan, Woerden, Netherland) intraperitoneal olarak verildi, uygun oda sıcaklığında spontan solunumlarına bırakıldı. Denekler yüzüstü sabitlendi, T7-8-9 seviyeleri belirlenip cerrahi öncesi temizliği yapıldı, povidion iyot ile antisepsi sağlandı. Orta hat insizyonu yapılıp, cilt ve cilt altı geçildi, paravertebral adaleler subperiosteal diseke edildi.

A grubunda, sadece T7-8-9 laminektomi yapıldı. B grubunda, T7-8-9 laminektomi yapıldıktan sonra spinal kord durası açığa çıkarıldı ve modifiye Allen ağırlık düşürme modeli ile travma oluşturuldu $(0,5 \mathrm{~cm}$ çaplı, 10 $\mathrm{cm}$ uzunluğundaki cam boru kullanılarak $10 \mathrm{~cm}$ yükseklikten $10 \mathrm{gr}$ ağırlık sağlam dura üzerine düşürüldü). C grubunda, T7-8-9 laminektomi yapıldıktan sonra dura açığa çıkarıldı ve ekstradural olarak kapanma basıncı $50 \mathrm{~g}$ olan anevrizma klipsi (Yaşargil, FE 619K, Aesculap AG, Almanya) ile omurilik travması oluşturuldu. Tüm denekler işlem sonrası anatomik bütünlüğe uygun olarak kapatıldı.
Biokimyasal analiz için, anestezi öncesi ve cerrahi işlem sonrası 12. saat, 1 . gün, 5 . gün ve 7. gün kuyruk kanı alındı. Spektrofotometrik yöntem ile albümin, katalaz, IMA, tiyol-disülfid dengesi bakıldı. Ratların sakrifikasyonu sonrası T7-8-9 bölgesindeki omurilik dokusu çıkarılarak TOS, TAS, OSi bakılarak, sonuçlar istatistiksel olarak değerlendirildi.

Fonksiyonel analiz için, tüm deneklere cerrahi prosedürden 12 saat sonra, 1. gün, 3. gün, 5. gün ve 7. gün Basso-Beattie and Bresnahan (BBB) skorları bakıldı. Her denek 5 dakikalık seanslar halinde değerlendirilmiş ve BBB skoru, gövde, kuyruk ve arka ekstremiteyi içeren davranışların gözlemlenmesi ve skorlanması ile belirlenmiştir. Her bir denek için üç muayeneden alınan puanların ortalaması alınmıştır (0: hareket yok; 21: normal hareket). Sonuçlar istatistiksel olarak değerlendirildi.

İstatistiksel analiz için, Veriler SPSS 15 (SPSS Inc; Chicago; IL, ABD) programı kullanılarak analiz edildi. Sayısal değişkenlerin normal dağılıma uygunluğu KolmogorovSmirnov testleri ile incelendi. Bağımsız gruplar arası fark Kruskal-Wallis testi sonrası MannWhitney $\mathrm{U}$ testi ile, bağımlı gruplar arası fark ise Friedman analizi ile yapıldı. Sonuçlar mean \pm SD olarak ifade edildi ve $p<0,05$ istatistiksel olarak anlamlı kabul edildi.

\section{Bulgular}

\section{Fonksiyonel sonuçlar}

Denekler, BBB skorları açısından değerlendirildiğinde B ile A grubu arasında 12. saatte ve 1 . günde istatistiksel anlamlı fark bulunamamıştır. Ancak, 3. gün, 5. gün ve 7 . gün değerleri arasında anlamlı farklılık saptanmıştır (sırasıyla $p=0,005, p=0,005, p=0,012$ ). A ile $C$ grubu arasında ise 12. saatte, 1 . günde, 3 . günde, 5 . günde ve 7 . günde istatistiksel anlamlı farklılık saptanmıştır (sırasıyla $p=0,01, p=0,009$, $p=0,005, p=0,005, p=0,012)$. B grubu ile C grubu arasında ise yine tüm zaman dilimlerinde istatistiksel açıdan anlamlı farklılık mevcuttu. Fonksiyonel sonuçlar gruplar içinde, zamana bağlı olarak değerlendirildiğinde C grubu B grubundan, $B$ grubu ise $A$ grubundan daha kötü fonksiyonel seyir göstermiştir (Tablo 1). 
Tablo 1. Deneklerin BBB skorlarının (0: hareket yok; 21: normal hareket) ortalama değerleri ve analizi

\begin{tabular}{lllll}
\hline Zaman & $\mathbf{A}$ & $\mathbf{B}$ & $\mathbf{C}$ & \\
\hline 12. saat & $6,5 \pm 0,58$ & $5,25 \pm 0,96$ & $0,25 \pm 0,5$ & $p=0,0$ y,z \\
1. gün & $12,5 \pm 0,58$ & $11,50 \pm 0,58$ & $8 \pm$ & $p=0,00^{y, z}$ \\
2. gün & 13 & $10,75 \pm 1,26$ & \pm 8 & $p=0,005^{x, y, z}$ \\
5. gün & 13 & $11 \pm 1,4$ & \pm 8 & $p=0,005^{x, y, z}$ \\
7. gün & 21 & $17,5 \pm 2,4$ & $14,75 \pm 0,96$ & $p=0,012^{x, y, z}$ \\
& $p=0,004$ & $p=0,005$ & $p=0,003$ & \\
\hline
\end{tabular}

x: A (kontrol) grubu ile B (ağırlık) grubu arasında istatistiksel anlamlı fark var,

y: A grubu ile C (klip-kompresyon) grubu arasında istatistiksel anlamlı fark var,

z: B grubu ile C grubu arasında istatistiksel anlamlı fark var)

\section{Biokimyasal sonuçlar}

Katalaz: Preop değerlerde gruplar arasında anlamlı bir fark yoktu. Deneklerin 12. saat değerlerinde de anlamlı bir farklılık saptanmamışken $(p=0,0874)$, 1. gün $A$ ile $B$ grubu veAile $C$ grubu arasında anlamlı bir farklılık saptanmıştır $(p=0,025)$. Yedinci gün ise $B$ ve $C$ grubunda, A grubuna göre istatistiksel anlamlı farklılık saptandığı gibi $B$ ve $C$ grubu arasında da anlamlı bir fark saptanmıştır $(p=0,012)$. Katalaz değerleri açısından değerlendirildiğinde, B ve C grubu arasındaki anlamlı fark 7. gün tespit edilmiştir. Katalaz değerlerinin zaman içerisinde değişimi değerlendirildiğinde ise $A$ grubunda 7. günde (ort: $84,09 \pm 12,16$ ) preop değere (ort: $82,75 \pm 15,52)$ yakın değer elde edilirken, C grubunda ise 7 . gün değerinde (ort: $30,88 \pm 2,01$ ) preop değere (ort: $65,52 \pm 9,37$ ) göre belirgin bir düşüş mevcuttu. C grubunda grup içi değerler baz alındığında, anlamlı farklılık yok iken $(p=0,077)$, A ve B grubunda grup içi değerler arasında anlamlı farklılık mevcuttu (sırasıyla $p=0,009, p=0,007$ ) (Tablo 2).

İskemi Modifiye Albumin (IMA): Gruplar arasında preop değerlerde anlamlı bir farklılık yoktu. A grubu ile B ve C grubu arasında istatistiksel açıdan anlamlı farklılık 12. saatte tespit edildiği gibi $(p=0,007), 1$. gün ve 7 . günde de tespit edilmiştir (sırasıyla $p=0,007, p=0,025$ ). Grup içi değerlerin zamansal değişimine bakıldığında, her üç grupta da istatistiksel açıdan anlamlı bir fark yoktu $(p>0,05)$ (Tablo 2$)$.

Native Tiyol (NT): Preoperativ değerlerinde gruplar arasında anlamlı farklılık yoktu. İstatistiksel olarak 12. saat ve 1. gün değerlerinde de gruplar arasında anlamlı farklılık saptanmadı (sırasıyla $p=0,155, p=0,390$ ). A ile $C$ grubu arasında 5 . gün istatistiksel anlamlı sonuç görüldü $(p=0,024)$. Yedinci gün $A$ ile $B$ grubu arasında ve $\mathrm{B}$ grubu ile $\mathrm{C}$ grubu arasında istatistiksel anlamlı sonuç izlendi $(p=0,018)$ (Tablo 2).

Total Tiyol (TT): Preoperativ değerler arasında istatistiksel açıdan anlamlı farklılık saptanmadı. Gruplar arasında 12. saatte, 1. gün, 5. gün bulguları açısından istatistiksel açıdan anlamlı fark görülmemiştir (sırasıyla $p=0,334$, $p=0,125, p=0,334)$. Yedinci gün değerlerinde $A$ ile $B$ grubu arasında ve B ile $C$ grubu arasında istatistiksel açıdan anlamlı fark saptanmıştır $(p=0,018)$ (Tablo 2).

Disülfid (SS): Preoperativ değerlerde gruplar arasında anlamlı farklılık görülmemiştir. Gruplar arasında 12. saat, 1. gün, 5. gün istatistiksel açıdan anlamlı fark saptanmamıştır $(p=0,368$, $p=0,092, p=0,232)$. Yedinci gün $B$ ve $C$ grubu arasında istatistiksel açıdan anlamlı fark saptanmıştır $(p=0,048)$ (Tablo 2$)$.

Disülfid/Native Tiyol, Disülfid/Total Tiyol, Native Tiyol/Total Tiyol: Gruplar arasında preoperativ değerler açısından anlamlı fark görülmemiştir. A ile B grubu arasında ve B ile $C$ grubu arasında 12 . saatte ve 1 . günde istatistiksel açıdan anlamlı fark saptanmıştır (sırasıyla $p=0,023, p=0,024$ ). Beşinci gün A ile C grubu arasında, 7. gün ise $B$ ile $C$ grubu arasında istatistiksel açıdan anlamlı fark saptanmıştır (sırasıyla $p=0,037, p=0,048$ ). Zamana göre gruplar içindeki değişime bakıldığından sadece A grubunda grup içinde zaman bağlı değişimde anlamlı fark saptanmıştır, $p=0,016$ ) (Tablo 2). 
Tablo 2. Biokimyasal markerların istatistiksel analiz sonuçları

\begin{tabular}{llllll}
\hline Serum parametreleri & Preop & 12. saat & 1. gün & 5. gün & 7. gün \\
\hline Katalaz & - & - & $+, p=0,025^{x, y}$ & $+, p<0,005^{x, y}$ & $+, p=0,012^{x, y, z}$ \\
İskemi modifiye Albumin & - & $+, p=0,007^{x, y, z}$ & $+, p=0,007^{x, y, z}$ & $+, p<0,005^{x, y, z}$ & $+, p=0,025^{x, y, z}$ \\
Native Tiol & - & - & - & $+, p=0,024^{y}$ & $+, p=0,018^{x, z}$ \\
Total tiol & - & - & - & - & $+, p=0,018^{y, z}$ \\
Disülfid & - & - & - & - & $+, p=0,048^{x, y, z}$ \\
\%Disülfid/Native Thiol & - &,$+ p=0.023^{x, z}$ &,$+ p=0.024^{x, z}$ &,$+ p=0.037^{y}$ &,$+ p=0.048^{z}$ \\
\% Disülfid/ Total Thiol & - &,$+ p=0.023^{x, z}$ &,$+ p=0.024^{x, z}$ &,$+ p=0.037^{y}$ &,$+ p=0.048^{z}$ \\
Native/Total Tiol & - &,$+ p=0.023^{x, z}$ &,$+ p=0.024^{x, z}$ &,$+ p=0.037^{y}$ &,$+ p=0.048^{z}$ \\
\hline
\end{tabular}

- : gruplar arasında istatistiksel anlamlı farklılık yok,

+ : gruplar arasında istatistiksel anlamlı farklılık var,

$\mathrm{x}$ : A (kontrol) grubu ile B (ağırlık) grubu arasında istatistiksel anlamlı fark var,

y: A grubu ile C (klip-kompresyon) grubu arasında istatistiksel anlamlı fark var,

z: B grubu ile $\mathrm{C}$ grubu arasında istatistiksel anlamlı fark var

TAS, TOS, OSI: Çalışmada 7. gün sakrifiye edilen ratların (Resim 1) omurilik dokularında TAS ve TOS bakıldı, OSi değerlendirildi. İstatistiksel açıdan TOS değerlerinde A (ort: $0,94 \pm 0,27$ ), B (ort: $0,83 \pm 0,19$ ) ve C (ort: $0,90 \pm 0,09)$ grupları arasında anlamlı bir fark bulanmamıştır $(p=0,390)$. Yine TOS değerleri arasında da A (ort: $33,63 \pm 2,67$ ), B (ort: $31,98 \pm 4,28$ ), C (ort: $29,05 \pm 3,57$ ) grupları arasında anlamlı fark görülmemiştir $(p=0,166)$. Ayrıca Osi değerlendirmesinde de gruplar arasında anlamlı farklılık saptanmamıştır $(p=0,5)$ (Tablo 3).
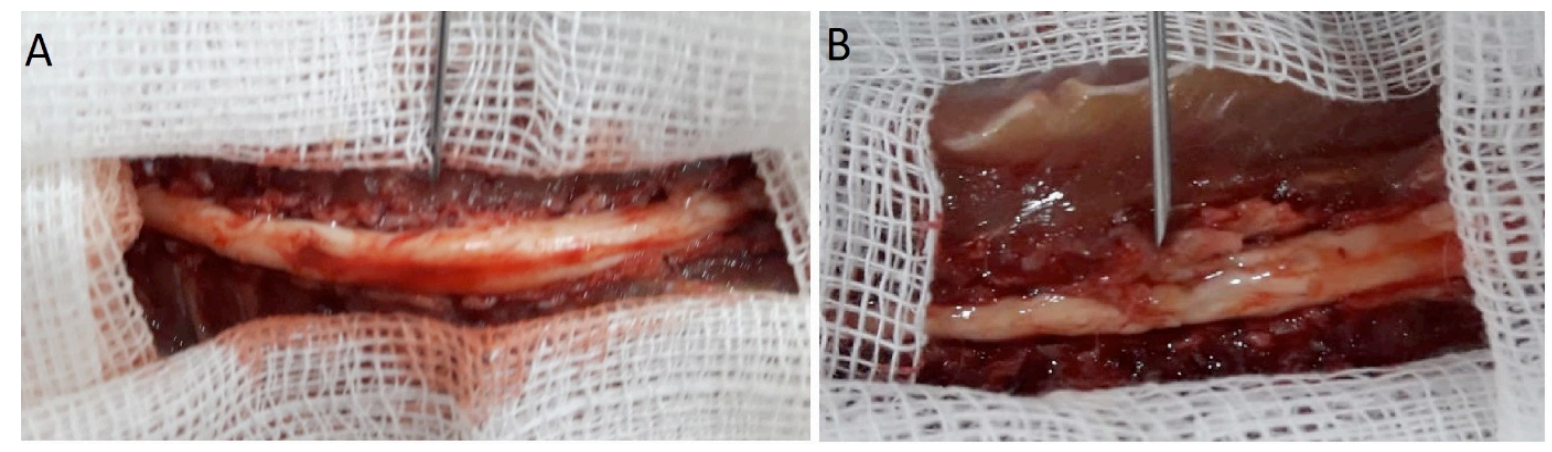

Resim 1 Denekler sakrifiye edildikten sonra ortaya çıkarılan omurilik dokuları.

A: Ağırlık düşürme tekniği ile omurilik travması oluşturulan denekte iğne ucu travma alanını göstermektedir.

B: Klip-kompresyon tekniği ile omurilik travması oluşturulan denekte iğne ucu hasar alanını göstermektedir. 
Tablo 3. Spinal kord dokusundan elde edilen TAS (Total antioksidan kapasite), TOS (Total oksidan kapasite), OSi (oksidatif stres indeksi) değerleri (mean \pm SD)

\begin{tabular}{lllll}
\hline Doku parametreleri & A & B & C & p değeri \\
\hline $\begin{array}{l}\text { TAS }(\mathrm{nmol} \text { Trolox Eqv/mg } \\
\text { protein) }\end{array}$ & $33,63 \pm 2,67$ & $31,98 \pm 4,28$ & $29,05 \pm 3,57$ & 0,166 \\
$\begin{array}{l}\text { TOS }\left(\mathrm{nmol} \mathrm{H} \mathrm{O}_{2} \text { Eqv/mg }\right. \\
\text { protein) }\end{array}$ & $0,94 \pm 0,27$ & $0,83 \pm 0,19$ & $0,90 \pm 0,09$ & 0,390 \\
Osi & $0,03 \pm 0,082$ & $0,028 \pm 0,005$ & $0,033 \pm 0,005$ & 0,5 \\
\hline
\end{tabular}

\section{Tartışma}

Dünyada halen önemli bir sağlık sorunu olan omurilik yaralanmasında [20] meydana gelen biokimyasal değişiklikliklerden üzerinde en fazla çalışılan konular, inflamasyon-antiinflamasyon ve oksidatif-antioksidatif yanıtlar olmuştur [2, $7-9,21,22]$.

Antioksidan savunma sistemi, oksidanların ve serbest radikallerin zararlı etkilerini nötralize ederek hücreleri korur. Uygun bir antioksidan yanıt alınamadığında hücresel hasar oluşur ve oksidatif strese neden olur [23]. Ayrıca, oksidan ve antioksidan kapasitenin ölçümü de oluşan hasar veya hasara yanıtı yansıtmaktadır [24]. Endojen antioksidanlar olan süperoksid dismutaz (SOD), katalaz ve glutatyon peroksidaz seviyeleri ile birçok hastalık arasında ilişki bulunmuştur $[8,23,25]$.

$\begin{array}{ccc}\text { Katalaz, hücrede temel olarak } & \\ \text { peroksizomlarda bulunan ve } \mathrm{H}_{2} \mathrm{O}_{2}\end{array}$ detoksifikasyonunda görev alan antioksidan bir enzimdir [26, 27]. Şizofreni ve epilepsi gibi bazı hastalıklarda ve spinal kord yaralanmalarında katalaz seviyesinde düşüklük olduğu bildirilmiştir [25-27]. Bu çalışmada, literatürden farklı olarak katalaz seviyesindeki değişikliklerin çalışmalarda kullanılabilirliği deneysel iki travma modelinde karşılaştırılarak değerlendirilmiştir. Bizim çalışmamızda hem 1. günde $(p=0,025)$ hem de 7 . günde $(p=0,012)$ klip-kompresyon grubunda travma ve kontrol grubuna göre anlamlı farklılık görülmüştür. Klip kompresyon grubunda katalaz seviyesindeki düşüş travma grubuna göre çok daha anlamlı bulunmuştur. $\mathrm{Bu}$ açıdan değerlendirildiğinde hasarın erken döneminde antioksidan yanıtın katalaz açısından belirgin farklılık göstermediği ancak hasarın ilerleyen günlerinde (7. günde) klip kompresyon grubunda antioksidan katalaz yanıtının daha belirgin düştüğü, bu grupta hasarın daha fazla oluştuğu görülmüştür. Literatürde, deneysel omurilik yaralanmalarında katalaz incelenmiş olsa da çalışmamız iki ayrı omurilik travma modelinde katalazı karşılaştırarak değerlendirmesi açısından farklılık oluşturmaktadır [25-27].

İskemi modifiye albümin (IMA), iskemik koşullarda oksijen radikallerinin albüminin N-terminaline hasar vermesiyle oluşan bir varyant proteindir. Klinik çalışmalarda, genellikle iskemik ataktan 6-12 saat içinde yükselmeye başlar ve 24 saat sonra da normal değerlerine düşmeye başlar [28-30]. Yine travmatik beyin yaralanmasında da IMA seviyesinin yükseldiği ve mortaliteyi tahmin etmede yüksek hassasiyet ve özgüllük ile kullanılabileceği belirtilmiştir [30]. Bu makalede, IMA seviyeleri en sık kullanılan iki deneysel omurilik yaralanması modelinde karşılaştırılmalı olarak incelenmiştir. Travmanın erken dönemimde IMA yükselmiş ancak ilerleyen dönemde düşerek tekrar bazal seviyelerine gelmiştir. Ancak oluşan hasarın şiddeti ile IMA düzeyleri arasında ise bir fark olmadığı görülmüştür. Travmanın erken döneminde kullanılabilecek bir belirteç olsa da ilerleyen dönemde IMA düzeyleri bir özellik göstermemektedir. Bu sonuç literatürde belirtilen IMA'nın iskeminin erken döneminde yükselmesi ve sonrasında normale gelmesi çıkarımlarıyla uyumludur [28-30].

Hücrelerde oksidatif stres oluşumunu önlemede kritik role sahip bileşenlerden biri olan tiyol, sülfidril (-SH) içeren organik bir bileşendir. Sistein, metiyonin gibi sülfür içeren aminoasitlerin tiyol gruplarının reaktif oksijen radikelleri oksitlenerek reversible disülfid bağlarına dönüşür. $\mathrm{Bu}$ mekanizma protein oksidasyonunun erken belirtisidir. Dinamik tiyol/ disülfid dengesinin antioksidan savunmada, apopitozda kritik öneme sahip olduğu klinik çalışmalar ile gösterilerek hasta takiplerinde 
kulllanılabileceği belirtilmiştir $[23,31-33]$. Ancak literatürde deneysel omurilik yaralanma modellerinde, klip kompresyon ve travma gruplarında karşılaştıılarak bakılan bir çalışma yoktur. Çalışmamızda 5. gün $(p=0,024)$ ve 7 . gün $(p=0,18)$ klip-kompresyon grubu ile travma ve kontrol grubu arasında ve travma ile kontrol grubu arasında anlamlı fark görülmüştür. Gruplar içinde zaman içinde NT değişimine bakıldığında ise klip-kompresyon grubunda istatistiksel anlamlı sonuç bulunamaz iken kontrol ve travma grubunda anlamlı düşüklük görülmüştür. Buradan hareketle travmanın erken belirteci olarak NT, iyi bir belirteç olamasa da geç dönemde bir belirteç olarak kullanılabilir. Ayrıca ağır hasar durumunda, NT seviyeleri daha belirgin düşüklük göstermektedir. Total tiyol değerlerinde ise, hasarın 12. saatinde 1. gününde ve 5 . gününde anlamlı değişiklik gösterecek düşüklük saptanmamış (sırasıyla $p=0,334, p=0,125, p=0,334)$, fakat 7 . gün kontrol grubu ile diğer gruplar arasında ve travma grubu ile klip-kompresyon grubu arasında anlamlı düşüklük saptanmıştır $(p=0,018)$. Zaman içinde grup içi TT ve SS seviyelerinde değişiklik ise kontrol grubunda, travma grubunda ve klip-kompresyon grubunda anlamlı bulunamadığı için, iki travma modelinde de bir belirteç olarak tek başına kullanılamayacağı sonucu doğmuştur. Spinal krod travması sonucu SS/NT, SS/TT ve NT/TT oranlarına da bakılmıştır. Parametreler incelendiğinde SS/ NT ile SS/TT değerlendirildiğinde travmanın erken ölçümlerinde, ara ölçümlerinde ve son ölçümlerinde kontrol grubuna göre gruplar arasında ve travma ile klip kompresyon grubu arasında anlamlı artış gösteren farklılık saptanmıştır (sırasıyla $p=0,023, \quad p=0,024$, $p=0,037, p=0,048)$. Klip-kompresyon grubunda SS/NT ölçümlerinin daha belirgin artış gösterdiği görülmüştür. Ayrıca hasarın şiddeti arttıkça SS/TT ve SS/NT değerleri daha fazla değişiklik gösterdiğinden, hasarın şiddetini değerlendirmek için de uygun bir belirteç olduğu kanısı oluşmuştur.

Hücresel düzeyde oksidan kapasite ve antioksidan kapasitenin denge halinde olması hücre fonksiyonlar açısından hayati öneme sahiptir. Hasarın şiddetini ya da terapotik etkinliği değerlendirmek için bu amaçla birçok araştırmacı TOS, TAS ve OSI parametrelerini kullanmıştır [34-37]. Bu çalışmada, oksidan ve antioksidan sistemin göstergesi olduğu iddia edilen bu parametreler, iki deneysel travma modelinde karşılaştırmalı olarak incelenmiştir. Gruplar sakrifiye edildikten sonra spinal kord dokusundan elde edilen sonuçlarda TAS ve TOS değerlerinde istatistiksel açıdan gruplar arasında anlamlı fark saptanmamıştır (sırasıyla $p=0,166, \quad p=0,390)$. Oksidatif stres indeksi açısından da gruplar arasında istatistiksel açıdan anlamlı bir fark görülmemiştir. Bu bulgulularla, çalışmamızda TAS, TOS ve OSI'nin her iki travma modelinde de bir parametre olarak kullanılamıyacağı sonucuna ulaşılmıştır.

Sonuç olarak, omurilik travmalarında hasarın önde gelen nedenlerinden biri oksidatif strestir. Deneysel omurilik travmalarında da biokimyasal olarak oksidatif stres belirteçlerinin bilinmesi ve analiz edilmesi, terapotik deneylerde yanıt değerlendirilmesi açısından ayrı bir öneme sahiptir. Çalışmamızda, iki farklı omurilik yaralanması değerlendirilmiştir ve biokimyasal olarak katalaz, SS/TS, SS//TT, TT/ ST parametrelerinin bu amaçla kullanılabileceği görülmüştür. Klip-kompresyon ile oluşturulan ağırlık düşürme modelinde hasarın daha ağır olması nedeniyle, ağırlık düşürme modeline göre daha kötü fonksiyonel sonuçlara ulaşılmıştır. Ayrıca fonksiyonel hasarın büyüklüğü ile biokimyasal oksidatif belirteçler arasında da iliş̧i bulunmuştur. IMA ise hasarın erken evresinde travma modellemelerinde artsa da takip eden günlerde normal değerlere gelmiştir.

Çıkar ilişkisi: Yazarlar arasında hiçbir çıkar çatışması bulunmamaktadır.

\section{Kaynaklar}

1. Kumar R, Lim J, Mekary RA, et al. Traumatic Spinal Injury: global epidemiology and worldwide volume. World Neurosurg 2018;113:345-363. https://doi. org/10.1016/j.wneu.2018.02.033

2. Cheriyan T, Ryan DJ, Weinreb JH, et al. Spinal cord injury models: a review. Spinal Cord 2014;52:588-595. https://doi.org/10.1038/sc.2014.91

3. Metz GAS, Curt A, van de Meent H, Klusman I, Schwab ME, Dietz V. Validation of the weight-drop contusion model in rats: a comparative study of human spinal cord injury. J Neurotrauma 2000;17:1-17. https://doi. org/10.1089/neu.2000.17.1

4. Abdullahi D, Annuar AA, Mohamad M, Aziz I, Sanusi J. Experimental spinal cord trauma: a review of mechanically induced spinal cord injury in rat models. Rev Neurosci 2017;28:15-20. https://doi.org/10.1515/ revneuro-2016-0050 
5. Paterniti I, Esposito E, Cuzzocrea S. An in vivo compression model of spinal cord injury. Methods Mol Biol 2018;1727:379-384. https://doi.org/10.1007/9781-4939-7571-6_29

6. Aras M, Altas M, Motor S, et al. Protective effects of minocycline on experimental spinal cord injury in rats. Injury 2015;46:1471-1474. https://doi.org/10.1016/j. injury.2015.05.018

7. Kjell J, Olson L. Rat models of spinal cord injury: from pathology to potential therapies. Dis Model Mech 2016;9:1125-1137. https://doi.org/10.1242/ dmm.025833

8. Lin $\mathrm{X}$, Zhu J, Ni $\mathrm{H}$, et al. Treatment With 2-BFI Attenuated spinal cord injury by inhibiting oxidative stress and neuronal apoptosis via the Nrf2 signaling pathway. Front Cell Neurosci 2019;13:567. https://doi. org/10.3389/fncel.2019.00567

9. Sharif Alhoseini M, Khormali M, Rezaei M, et al. Animal models of spinal cord injury: a systematic review. Spinal Cord 2017;55:714-721. https://doi.org/10.1038/ sc.2016.187

10. Cho ES, Jang YJ, Hwang MK, Kang NJ, Lee KW, Lee HJ. Attenuation of oxidative neuronal cell death by coffee phenolic phytochemicals. Mutat Res 2009;661:18-24. https://doi.org/10.1016/j.mrfmmm.2008.10.021

11. Dumont RJ, Verma S, Okonkwo DO, et al. Acute spinal cord injury, part II: contemporary pharmacotherapy. Clin Neuropharmacol 2001;24:265-279. https://doi. org/10.1097/00002826-200109000-00003

12. Evsen MS, Ozler A, Gocmez C, et al. Effects of estrogen, estrogen/progesteron combination and genistein treatments on oxidant/antioxidant status in the brain of ovariectomized rats. Eur Rev Med Pharmacol Sci 2013;17:1869-1873.

13. Kermani HR, Nakhaee N, Fatahian R, Najar AG. Effect of Aspirin on Spinal Cord Injury: an Experimental Study. Iran J Med Sci 2016;41:217-222.

14. Erel O. A new automated colorimetric method for measuring total oxidant status. Clin Biochem 2005;38:1103-1111. https://doi.org/10.1016/j. clinbiochem.2005.08.008

15. Erel O. A novel automated direct measurement method for total antioxidant capacity using a new generation, more stable ABTS radical cation. Clin Biochem 2004;37:277-285. https://doi.org/10.1016/j. clinbiochem.2003.11.015

16. Lowry $\mathrm{OH}$, Rosebrough $\mathrm{NJ}$, Farr AL, Randall RJ. Protein measurement with the Folin phenol reagent. J Biol Chem 1951;193:265-275.

17. Erel O, Neselioglu S. A novel and automated assay for thiol/disulphide homeostasis. Clin Biochem 2014;47:326-332. https://doi.org/10.1016/j. clinbiochem.2014.09.026
18. Bar Or D, Winkler JV, Vanbenthuysen K, Harris L, Lau E, Hetzel FW. Reduced albumin-cobalt binding with transient myocardial ischemia after elective percutaneous transluminal coronary angioplasty: a preliminary comparison to creatine kinase-MB, myoglobin, and troponin I. Am Heart J 2001;141:985991. https://doi.org/10.1067/mhj.2001.114800

19. Goth L. A simple method for determination of serum catalase activity and revision of reference range. Clin Chim Acta 1991;196:143-151. https://doi. org/10.1016/0009-8981(91)90067-m

20. Devivo MJ. Epidemiology of traumatic spinal cord injury: trends and future implications. Spinal Cord 2012;50:365-372. https://doi.org/10.1038/sc.2011.178

21. Klusman I, Schwab ME. Effects of pro-inflammatory cytokines in experimental spinal cord injury. Brain Res 1997;762:173-184. https://doi.org/10.1016/s00068993(97)00381-8

22. Hall ED, Braughler JM. Free radicals in CNS injury. Res Publ Assoc Res Nerv Ment Dis 1993;71:81-105.

23. Singh E, Devasahayam G. Neurodegeneration by oxidative stress: a review on prospective use of small molecules for neuroprotection. Mol Biol Rep 2020;47:3133-3140. https://doi.org/10.1007/s11033020-05354-1

24. Kuyumcu F, Aycan A. Evaluation of oxidative stress levels and antioxidant enzyme activities in burst fractures. Med Sci Monit 2018;24:225-234. https://doi. org $/ 10.12659 / \mathrm{msm} .908312$

25. Samarghandian S, Azimi Nezhad M, Farkhondeh $T$, Samini F. Anti-oxidative effects of curcumin on immobilization-induced oxidative stress in rat brain, liver and kidney. Biomed Pharmacother 2017;87:223229. https://doi.org/10.1016/j.biopha.2016.12.105

26. Lee YS, Sindhu RK, Lin CY, Ehdaie A, Lin VW, Vaziri ND. Effects of nerve graft on nitric oxide synthase, NAD(P) $\mathrm{H}$ oxidase, and antioxidant enzymes in chronic spinal cord injury. Free Radic Biol Med 2004;36:330-339. https://doi.org/10.1016/j.freeradbiomed.2003.11.006

27. Vaziri ND, Lee YS, Lin CY, Lin VW, Sindhu RK. NAD(P) $\mathrm{H}$ oxidase, superoxide dismutase, catalase, glutathione peroxidase and nitric oxide synthase expression in subacute spinal cord injury. Brain Res 2004;995:76-83. https://doi.org/10.1016/j.brainres.2003.09.056

28. Oran I, Oran B. Ischemia-modified albumin as a marker of acute coronary syndrome: the case for revising the concept of "N-terminal modification" to "fatty acid occupation" of albumin. Dis Markers 2017;2017:8. https://doi.org/10.1155/2017/5692583

29. Coverdale JPC, Katundu KGH, Sobczak AIS, Arya $S$, Blindauer CA, Stewart AJ. Ischemia-modified albumin: crosstalk between fatty acid and cobalt binding. Prostaglandins Leukot Essent Fatty Acids 2018;135:147-157. https://doi.org/10.1016/j. plefa.2018.07.014 
30. Radwan TAM, Fahmy RS, El Emady MFM, et al. Ischemia-modified albumin as a biomarker for prediction of poor outcome in patients with traumatic brain injury: an observational cohort study. J Neurosurg Anesthesiol 2019. https://doi.org/10.1097/ ANA.0000000000000647

31. Gunduztepe Y, Bukan N, Zorlu E, et al. The evaluation of thiol-disulfite balance, ischemia albumin modification and seruloplazmine as a new oxidative stress in mild cognitive impairment and early stage alzheimer's disease patients. J Clin Neurosci 2020;75:188-194. https://doi.org/10.1016/j.jocn.2019.12.026

32. Giden R, Gokdemir MT, Erel O, Buyukaslan H, Karabag $\mathrm{H}$. The relationship between serum thiol levels and thiol/ disulfide homeostasis with head trauma in Children. Clin Lab 2018;64:163-168. https://doi.org/10.7754/ Clin.Lab.2017.170816

33. Erel O, Erdogan S. Thiol disulfide homeostasis: an integrated approach with biochemical and clinical aspects. Turk J Med Sci 2020. https://doi.org/10.3906/ sag-2003-64

34. Liu J, Peng L, Li J. The Lipoxin A4 receptor agonist BML111 alleviates inflammatory injury and oxidative stress in spinal cord injury. Med Sci Monit 2020;26:e919883. https://doi.org/10.12659/MSM.919883

35. Yu L, Qian J. Dihydrotanshinone I Alleviates spinal cord Injury via suppressing inflammatory response, oxidative stress and apoptosis in rats. Med Sci Monit 2020;26:e920738. https://doi.org/10.12659/ MSM.920738

36. Karatas Y, Erdi MF, Kaya B, et al. Neuroprotective effects of tocilizumab on experimentally-induced spinal cord ischemia-reperfusion injury. World Neurosurg 2019;124:208-213. https://doi.org/10.1016/j. wneu.2018.12.069

37. Sayhan MB, Oguz S, Salt O, Can N, Ozgurtas T, Yalta TD. Sesamin ameliorates mucosal tissue injury of mesenteric ischemia and reperfusion in an experimental rat model. Arch Med Sci 2019;15:15821588. https://doi.org/10.5114/aoms.2017.68535

Etik kurul onayı: Bu çalışma Kobay A.Ş. Yerel Etik Kurulu tarafından 01.09.2019 tarih ve 333 protokol numarası ile onaylanmıştır.

\section{Yazarların makaleye olan katkıları}

E.B. bu çalışmanın ana fikrini ve hipotezini kurgulamıştır. E.B., Ş.H., A.S.A., C.B. ve B.G.Ö. teoriyi geliştirmiş ve materyel metod bölümünü düzenlemişlerdir. Sonuçlar kısmındaki verilerin değerlendirmesini E.B., Ş.H., C.B. ve A.Ş. yapmışlardır. Makalenin tartışma bölümü E.B., B.B. ve Ö.F.T. tarafından yazıımış, E.B. ve Ş.H. gözden geçirip gerekli düzeltmeleri yapmış ve onaylamıştır. Ayrıca tüm yazarlar çalışmanın tamamını tartışmıs ve son halini onaylamıştır. 